\title{
Strategi Pengembangan Usaha Ternak Babi Program Perak di Kabupaten Ngada
}

\section{Strategy for Developing Pig Population of Perak Program in Ngada Regency}

\author{
E. D. N. Wea ${ }^{1 *}$, M. Y. Luruk ${ }^{2}$, dan U. R. Lole ${ }^{2}$ \\ ${ }^{1}$ Program Studi Ilmu Peternakan, Program Pascasarjana, Universitas Nusa Cendana, Kupang - Indonesia \\ ${ }^{2}$ Fakultas Peternakan, Universitas Nusa Cendana, Kupang - Indonesia \\ *Corresponding E-mail: leonardwwea@gmail.com \\ (Diterima: 14 Februari 2020; Disetujui: 15 Mei 2020)
}

\begin{abstract}
ABSTRAK
Penelitian ini telah dilaksanakan di Kabupaten Ngada pada bulan April sampai Juli 2018. Penelitian ini bertujuan untuk: 1) Mengetahui dan menganalisis faktor-faktor apa saja yang mempengaruhi tingkat perkembangan populasi ternak babi, 2) Mengetahui dan menganalisis berapa besar pendapatan tunai usaha ternak babi, dan 3) Merumuskan strategi program PERAK untuk pengembangan populasi ternak babi dalam meningkatkan pendapatan anggota. Teknik pengambilan contoh dilakukan melalui tiga tahap yaitu penentuan kecamatan contoh secara purposif, penentuan desa contoh secara purposif dan penentuan responden contoh secara acak proporsional dimana setiap desa diambil 25\% dari kepala keluarga miskin sasaran dan diperoleh 100 responden. Data dianalisis menggunakan analisis regresi linier, analisis pendapatan, dan analisis SWOT. Pengambilan sampel yang dilakukan kepada responden SWOT yaitu teknik purposif sampling sehingga diambil 20 orang sebagai responden. Hasil penelitian dengan menggunakan uji regresi menunjukkan bahwa faktor yang mempengaruhi perkembangan populasi yaitu jumlah induk $\left(\mathrm{X}_{1}\right)$, tingkat kelahiran $\left(\mathrm{X}_{2}\right)$, dan koefisien determinasi $\left(\mathrm{R}^{2}=0,75\right)$. Rata-rata pendapatan tunai usaha ternak babi program PERAK sebesar Rp7.893.613. Analisis SWOT menunjukkan bahwa usaha ternak babi program PERAK di Kabupaten Ngada berada pada strategi agresif dan posisi ini merupakan situasi yang sangat menguntungkan. Strategi yang harus diterapkan dalam kondisi ini adalah mendukung kebijakan pertumbuhan yang agresif (growthoriented strategy). Program strategis yang perlu diterapkan adalah:1) Strategi peningkatan populasi ternak babi program PERAK, 2) Strategi peningkatan sumberdaya manusia (SDM), 3) Strategi optimalisasi penggunaan sumberdaya alam, dan 4) Strategi pengembangan dan penerapan teknologi.
\end{abstract}

Kata kunci: program PERAK, keluarga sasaran, dinamika populasi, pendapatan tunai, strategi agresif

\section{ABSTRACT}

The research was conducted in Ngada regency from April to July 2018. The study aims to: 1) evaluating and analyzing the factors influencing the development of pig population, 2) evaluating and analyzing the income of pig farm, and 3) formulating the strategy of PERAK Program for developing pig population and increasing members' income. Sampling was carried out in 3 steps: purposive sampling districts, purposive sampling village, and randomly proportional sampling respondents by selecting $25 \%$ of a low-income family to find out 100 respondents. Purposive sampling was then applied to select 20 SWOT respondents. Data analysis using dynamic population, income analysis, linear regression analysis, and SWOT analysis. The results found that Pig farm development PERAK Program in districts Ngada has increased $15 \%$ pig population in 3 years or 5\% per year. Regression analysis found that factors influencing pig population are: cows amount (X1), motility (X2), and coefficient determination $(R 2=0,75)$. The average cash income of the pig PERAK program is Rp7,893,613. SWOT analysis found that the PERAK Program of developing pig in Kabupaten Ngada is in Quadrant 1 means that the program is feasible and profitable. The recommended strategy for the program is by accelerating the aggressive growth-oriented strategy. The strategic programs to be implemented are; 1) Strategy to increase pig population PERAK program, 2) Strategy increase human resources, 3) Strategy for optimizing the use of natural resources, 3) Strategy optimizing the use of natural resources, and 4) Strategy development and application technology. 
Keywords: program PERAK, target family, dynamic population, cash income, aggressive strategy

\section{PENDAHULUAN}

Pelaksanaan pembangunan bertujuan untuk mewujudkan masyarakat yang adil, makmur dan sejahtera lahir, bathin, material, dan spiritual berdasarkan Pancasila dan Undang-Undang Dasar 1945. Pembangunan merupakan suatu proses yang dinamis dan multidimensional untuk mencapai kesejahteraan masyarakat yang lebih tinggi, mencakup berbagai perubahan mendasar atas struktur sosial dan institusi-institusi nasional dengan tetap mengejar akselerasi pertumbuhan ekonomi, penanganan ketimpangan pendapatan, serta pengentasan kemiskinan.

Kabupaten Ngada merupakan salah satu daerah di Provinsi Nusa Tenggara Timur (NTT) yang mayoritas penduduknya bekerja pada sektor pertanian. Kurang lebih 83,77\% penduduk di Kabupaten Ngada menjadikan sektor pertanian sebagai lapangan kerja utama dan sub sektor peternakan sebagai usaha sambilan. Sektor pertanian menjadi penyumbang terbesar Produk Domestik Regional Bruto (PDRB) Kabupaten Ngada yaitu 44,3\% (BPS, 2010). Hasil pendataan yang dilakukan oleh dinas BPMPD-PP dan KCS tercatat jumlah keluarga miskin sebanyak 15.955 KK dari total 30.037 KK (BPMPD-PP, 2010). Hal ini menunjukkan bahwa sebagian besar masyarakat yang berada di pedesaan tergolong miskin.

Pemerintah Daerah Kabupaten Ngada menyadari bahwa kemiskinan merupakan suatu permasalahan utama dan memerlukan langkah-langkah penanganan dan pendekatan sistematik, terpadu dan menyeluruh dengan langkah-langkah yang komperhensif. Untuk mewujudkan kesejahteraan rakyat maka salah satu upaya yang dilakukan Pemerintah Daerah dalam mengentaskan kemiskinan adalah melalui bantuan modal usaha ekonomi produktif melalui program Pemberdayaan Ekonomi Rakyat (PERAK) usaha ternak babi bagi keluarga miskin.
Komoditas peternakan khususnya ternak babi yang menjadi pilihan pemerintah dalam program PERAK ini berdasarkan pertimbangan bahwa ternak babi memiliki potensi pasar yang tinggi, baik di pasar lokal maupun antar pulau. Hal ini didukung dengan potensi sumberdaya alam yang melimpah dan belum termanfaatkan secara maksimal serta keinginan atau minat yang tinggi dari masyarakat untuk memelihara ternak babi. Selain itu, ternak babi mempunyai nilai tersendiri dalam kehidupan sosial budaya masyarakat setempat sehingga menjadikannya sebagai salah satu komoditi dengan harga jual yang tinggi.

Usaha ternak babi pada umumnya dilakukan oleh peternakan rakyat secara perorangan atau individu, yang mengakibatkan peternak tidak memiliki akses terhadap pasar, posisi tawarnya rendah, biaya pemasaran tinggi, tidak mampu memanfaatkan peluang pasar, pengetahuan dan teknologi rendah, dan kurangnya akses layanan dari pemerintah.

Petunjuk teknis Program PERAK pada Dinas P3 Ngada tahun 2011-2014 untuk program PERAK usaha ternak babi, yang menjadi indikator perannya terdiri dari: Hasil: 1) Meningkatkan populasi ternak babi, 2) Meningkatkan kemampuan keluarga miskin dalam menjalankan usaha ternak babi, dan 3) Meningkatnya pendapatan keluarga miskin, Manfaat: 1) Berkembangnya usaha agribisnis peternakan babi, dan 2) Merubah perilaku dan pola pikir keluarga miskin secara bertahap menjadi keluarga miskin mandiri. Evaluasi yang dilakukan Dinas P3 di tahun 2013, menunjukkan bahwa peningkatan populasi ternak babi PERAK dan peningkatan pendapatan keluarga miskin penerima program PERAK yang menjadi salah satu indikator keberhasilan program PERAK, sangat ditentukan oleh pola pengelolaan atau implementasi program PERAK dan manajemen kelompok PERAK.

Untuk dapat mengembangkan usaha ternak babi agar dapat berdaya saing 
dibutuhkan strategi yang tepat. Untuk mengetahui strategi pengembangan usaha, dapat ditentukan dengan kombinasi faktor internal dan faktor eksternal dalam peternakan. Kedua faktor tersebut dapat dipertimbangkan dalam analisis SWOT (Stengths, Weaknesess, Opportunities, Threats). Analisis SWOT membandingkan antara faktor eksternal (peluang dan ancaman) dengan faktor internal (kekuatan dan kelemahan) untuk membuat solusi atau strategi yang sesuai dengan keadaan nyata di lapangan. Dalam penelitian yang dilakukan oleh (Putri, 2018) metode analisis yang digunakan dalam penelitian strategi pengembangan usaha peternakan babi Bali, menggunakan analisis lingkungan internal dan eksternal untuk mengetahui kekuatan, kelemahan, peluang, dan ancaman yang ada dalam usaha peternakan babi.

Hasil observasi lapangan menunjukkan bahwa terjadi penurunan populasi ternak babi yang berimplikasi terhadap rendahnya pendapatan keluarga miskin. Hal itu disebabkan oleh beberapa faktor antara lain: 1) Peran pendamping PERAK dalam seluruh proses agribisnis ternak babi tidak maksimal, dimana peran pendamping hanya dilakukan ketika proses awal pengadaan ternak dan ketika ada ternak yang sakit, 2) Spesifikasi ternak babi tidak sesuai petunjuk teknis, dimana ternak babi yang diadakan sendiri oleh keluarga miskin adalah ternak babi yang belum siap kawin, 3) Pelayanan kesehatan ternak oleh petugas tidak maksimal, dimana terjadi keterlambatan informasi dari peternak kepada petugas kesehatan hewan dan jarak tempat tinggal petugas yang jauh, dan 4) Kematian anak babi tinggi disebabkan oleh stres nutrisi karena kekurangan air susu induk dan pakan berkualitas.

Permasalahan ini penting untuk diteliti, karena hasil penelitiannya diharapkan mampu memberikan manfaat bagi masyarakat agar memaksimalkan sumber daya alam, sosial, ekonomi, budaya dan sumber daya manusia yang ada guna meningkatkan kesejahteraan para anggota kelompok. Penelitian ini juga diharapkan menjadi bahan acuan bagi pemerintah setempat dalam membuat program-program terkait dengan bidang peternakanyang mampu meningkatkan kesejahteraan masyarakat.

Berdasarkan dasar pemikiran ini, maka telah dilakukan suatu penelitian untuk menghasilkan strategi-strategi yang dapat digunakan untuk meningkatkan populasi ternak babi sehingga pendapatan anggota kelompok dapat ditingkatkan.

\section{METODE}

Penelitian ini dilaksanakan pada bulan April sampai Juli 2018 di Kabupaten Ngada, Provinsi Nusa Tenggara Timur. Metode penentuan lokasi penelitian dilakukan melalui tiga tahap. Tahap pertama adalah penentuan kecamatan contoh secara purposive sampling. Tahap kedua adalah penentuan desa contoh secara purposive sampling sebanyak 2 Desa pada tiap-tiap Kecamatan contoh. Dengan demikian diperoleh 8 desa contoh yaitu: Desa Naruwolo II, Sadha, Paupaga, Jawameze, Naru, Tiwuriwu, Radabatha, dan Aimere Timur. Tahap ketiga adalah penentuan responden contoh secara acak proporsional dimana setiap desa diambil 25\% dari kepala keluarga miskin sasaran sehingga diperoleh $100 \mathrm{KK}$ peserta program Perak ternak babi sebagai responden representatif.

Penelitian ini menggunakan metode survei melalui observasi dan wawancara. Populasi dalam penelitian ini yakni Kepala keluarga miskin penerima bantuan program PERAK. Jenis data meliputi data primer dan data sekunder.

\section{Analisa Data}

Untuk menganalisis faktor-faktor yang mempengarui perkembangan populasi ternak, dianalisis dengan pendekatan uji statistik regresi linier berganda sesuai petunjuk (Muhidin dan Abdurahman, 2007) dengan rumus sebagai berikut:

$$
\begin{aligned}
\mathrm{Y}= & \mathrm{a}+\mathrm{b}_{1} \mathrm{X}_{1}+\mathrm{b}_{2} \mathrm{X}_{2}+\mathrm{b}_{3} \mathrm{X}_{3}+\mathrm{b}_{4} \mathrm{X}_{4}+\mathrm{b}_{5} \mathrm{X}_{5}+\ldots \ldots \\
& \mathrm{b}_{6} \mathrm{X}_{6}+\mathrm{e}_{\mathrm{i}}
\end{aligned}
$$


Keterangan:

$\mathrm{Y}=$ populasi ternak babi PERAK

$\mathrm{X}_{1}=$ jumlah induk ternak babi

$\mathrm{X}_{2}=$ tingkat kelahiran

$\mathrm{X}_{3}=$ tingkat kematian

$\mathrm{X}_{4}=$ umur sapih

$\mathrm{X}_{5}=$ interval kelahiran

$\mathrm{X}_{6}=$ sex ratio

$\mathrm{A}=$ parameter estimasi yaitu intersep atau konstanta

$\mathrm{b}_{1}, \mathrm{~b}_{2}, . . \mathrm{b}_{6}=$ koefisien regresi

$\mathrm{e}_{\mathrm{i}}=$ variabel pengganggu atau kesalahan (disturbances/ eror terms)

Untuk mengetahui peran program PERAK terhadap pendapatan dari usaha ternak babi anggota kelompok PERAK maka akan dilakukan analisis ekonomi berupa perhitungan input-output dimaksudkan untuk mengetahui berapa besar pendapatan tunai dari usaha ternak babi. Analisis tersebut dilakukan sesuai petunjuk Soekartawi (2003) dengan rumus sebagai berikut:

$$
\mathrm{Pd}_{\mathrm{utb}}=\mathrm{Pt}_{\mathrm{utb}}-\mathrm{Bt}_{\mathrm{utb}}
$$

Keterangan:

$\mathrm{Pd}_{\mathrm{utb}}=$ pendapatan tunai usaha ternak babi

$\mathrm{Pt}_{\text {utb }}=$ penerimaan total usaha ternak babi

$\mathrm{Bt}_{\mathrm{utb}}=$ biaya tunai usaha ternak babi

Untuk menganalisis strategi pemberdayaan ekonomi rakyat (PERAK) usaha ternak babi dalam meningkatkan populasi dan pendapatan menggunakan analisis SWOT. Dalam analisis SWOT terdapat tiga tahapan dalam proses penyusunan perencanaan strategis (Rangkuti, 2015) yakni: tahap pengumpulan data, tahap analisis, dan tahap pengambilan keputusan.

\section{HASIL DAN PEMBAHASAN}

\section{Gambaran Umum Ternak Babi PERAK}

Pemberdayaan Ekonomi Rakyat (PERAK) merupakan program yang dicanangkan oleh Pemerintah Daerah Kabupaten Ngada dengan tujuan meningkatkan produksi pangan asal ternak berupa daging, susu, telur, memperluas lapangan kerja, meningkatkan pendapatan petani peternak serta pemerataan pendapatan. Selain itu tujuan program PERAK lainnyaadalah meningkatkan populasi ternak dan memperbaiki genetik ternak khususnya untuk ternak babi dan menjadikan Kabupaten Ngada sebagai daerah penghasil ternak (Dinas P3 Kabupaten Ngada, 2011).

Program bantuan ternak babi ini disebarkan di Kabupaten Ngada sejak tahun 2011 sampai sekarang ini, dimana ternak yang diberikan berupa ternak sapi bibit. Penyebaran ternak dilakukan secara kelompok dimana tiap kelompok terdiri dari 9-11 orang anggota kelompok. Setiap kelompok mendapatkan 10 ekor ternak babi betina dan 10 ekor ternak babi jantan.

\section{Faktor-Faktor Yang Mempengaruhi Perkembangan Populasi}

Hasil penelitian menunjukan bahwa hubungan antara faktor-faktor yang mempengaruhi perkembangan populasi usaha ternak babi di Kabupaten Ngada dapat dilihat dari koefisien korelasi dan regresi yang diperoleh. Terdapat beberapa faktor yang berhubungan dengan perkembangan populasi ternak babi yaitu jumlah Induk $\left(\mathrm{X}_{1}\right)$, tingkat kelahiran $\left(\mathrm{X}_{2}\right)$, tingkat kematian $\left(\mathrm{X}_{3}\right)$, umur sapih $\left(\mathrm{X}_{4}\right)$, interval kelahiran $\left(\mathrm{X}_{5}\right)$, dan sex ratio $\left(\mathrm{X}_{6}\right)$.

Berdasarkan hasil analisis korelasi dapat dilihat bahwa dari keenam faktor yang telah diidentifikasi, hanya terdapat dua faktor yang memiliki hubungan yang nyata terhadap perkembangan populasi usaha ternak babi yakni, faktor yang memiliki korelasi nyata terhadap perkembangan populasi ternak babi yakni $\mathrm{X}_{1}$ (jumlah induk), dan $\mathrm{X}_{2}$ (tingkat kelahiran) sehingga dalam analisis regresi kedua faktor tersebut diikutsertakan (Tabel 1).

Meningkatnya jumlah populasi ternak babi pada program PERAK tidak terlepas dari bibit yang digunakan yaitu babi peranakan VDL sehingga cepat mencapai masa pubertasnya bila dibandingkan dengan babi lokal. Babi yang cepat mencapai masa pubertasnya akan dikawinkan dan akan 
Tabel 1. Korelasi antara perkembangan populasi ternak babi program PERAK (Y) dengan faktorfaktor yang diidentifikasi $(\mathrm{X})$ pada usaha ternak babi program PERAK di Kabupaten Ngada

\begin{tabular}{lccc}
\hline Variabel & Populasi (Y) & Signifikasi & Keterangan \\
\hline Jumlah induk (X1) & 0.814 & 0.000 & Nyata \\
Tingkat kelahiran (X2) & 0.828 & 0.000 & Nyata \\
Tingkat kematian (X3) & 0.417 & 0.397 & TidakNyata \\
Umur sapih (X4) & -0.058 & 0.818 & Tidak nyata \\
Interval kelahiran (X5) & -0.049 & 0.413 & Tidak nyata \\
Sex ratio (X6) & 0.285 & $-0,061$ & Tidak nyata \\
\hline
\end{tabular}

Sumber: Data primer 2019 (diolah)

cepat mendapat anak. Seekor babi dara akan mengalami pubertas pada umur 4-7 bulan. Hasil pengamatan dilapangan menunjukkan bahwa setiap babi betina akan dikawinkan ketika memasuki umur 8 bulan tepat pada hari kedua masa estrus dengan sistem perkawinan kawin alam. Walaupun teknik perkawinan yang digunakan adalah kawin alam namun tingkat kebuntingan dan kelahirannya tinggi sehingga mampu meningkatkan jumlah populasi ternak. Tingkat kelahiran ternak babi program PERAK mencapai $80 \%$.

Faktor yang memiliki korelasi tidak nyata terhadap perkembangan populasi usaha ternak babi yakni $\mathrm{X}_{3}$ (tingkat kematian), $\mathrm{X}_{4}$ (umur sapih), $\mathrm{X}_{5}$ (interval kelahiran), dan $\mathrm{X}_{6}$ (sex ratio). Berdasarkan hasil pengamatan di lapangan menunjukkan bahwa tingkat kematian ternak babi mencapai 20\%. Hal ini dipengaruhi oleh: 1) Produksi susu induk yang rendah, hal ini disebabkan karena nutrisi induk belum tercukupi untuk produksi susu sehingga anak babi juga kekurangan nutrisi. Menurut Prasetyo et al. (2013) produksi susu induk sangat berpengaruh terhadap pertumbuhan pedet saat menyusu. Penyebab kegagalan produksi air susu yaitu udara terlalu panas atau terlalu dingin, terjadi diare atau konstipasi, pergantian tempat yang mendadak, ransum yang tidak sempurna, kepayahan waktu melahirkan, adanya penyakit kelamin atau penyakit mastitis, dan keturunan dari induk yang selalu sedikit, 2) Kurangnya pengawasan, sebagian besar induk beranak pada malam hari sehingga peternak tidak sempat untuk menolong induk yang beranak sehingga ada anak babi yang terindih dan mati. Selain itu, jarak antara kandang dan rumah peternak yang cukup jauh mengakibatkan pengawasan kurang maksimal.

Hasil pengamatan di lapangan menunjukkan bahwa rata-rata umur sapi anak babi mencapai 3 bulan. Hal ini dikarenakan anak babi tidak mendapat cukup nutrisi sehingga memperlama umur sapih anak babi. Menurut Ardana et al. (2008) ada beberapa sistem penyapihan yang biasa dilakukan oleh peternak yaitu sistem penyapihan anak umur 4-6 minggu, umur 3-4 minggu, dan sistem penyapihan dini pada umur 14-19 hari. Berdasarkan hasil pengamatan di lapangan menunjukkan bahwa interval kelahiran babi program PERAK mencapai 7 bulan. Lamanya interval kelahiran dipengaruhi oleh umur sapih yang cukup lama yaitu mencapai 3 bulan. Purba et al. (2014) menyatakan bahwa pemilihan sistem penyapihan tergantung pada dampak masing-masing sistem penyapihan tersebut terhadap kinerja reproduksi induk selanjutnya, laju pertumbuhan anak, dan penggunaan kandang melahirkan secara efisien.

Berdasarkan hasil analisis regresi diperoleh koefisien regresi sebagai berikut: $\mathrm{b} 0=3,086, \mathrm{~b} 1=0,423, \mathrm{~b} 2=0,492$ (Tabel 2). Pengaruh dari faktor-faktor terhadap dinamika populasi melalui persamaan regresi sebagai berikut: 
Tabel 2. Hasil analisis regresi untuk mengetahui perkembangan populasi ternak babi program PERAK di Kabupaten Ngada

\begin{tabular}{clccc}
\hline No & Faktor & Koefisien & $\mathrm{T}_{\text {hitung }}$ & Sig \\
\hline 1 & Jumlah Induk $(\mathrm{x} 1)$ & 0,423 & 5,049 & .000 \\
2 & Tingkat kelahiran $(\mathrm{x} 2)$ & 0,492 & 5,876 & .000 \\
\hline Constanta & \multicolumn{3}{c}{3,086} \\
& $\mathrm{R}^{2}$ & $75 \%$ & \\
\hline
\end{tabular}

Sumber: Data primer 2019 (diolah)

Tabel 3. Analisis variasi regresi faktor-faktor yang mempengarui perkembangan populasi ternak babi program PERAK di Kabupaten Ngada

\begin{tabular}{lccccc}
\hline Keterangan & Derajat bebas & Jumlah kuadrat & Kuadrat tengah & F hitung & Signifikasi \\
\hline Regresi & 2 & 16,995 & 8,497 & 146,270 & $.000^{\mathrm{b}}$ \\
Residual & 97 & 5,635 & 058 & & \\
Total & 99 & 22,630 & & & \\
\hline
\end{tabular}

Sumber: Data primer hasil analisis 2019

$$
\mathrm{Y}=3,086+0,423 \mathrm{X}_{1}+0,492 \mathrm{X}_{2}\left(\mathrm{R}^{2}=0,75\right)
$$

Koefisien regresi $\mathrm{b} 1=0,423$ memiliki arti bahwa dengan meningkatnya jumlah induk sebesar 1\% maka populasi akan bertambah sebesar $0,423 \%$, Citerus peribus. Koefisien regresi $\mathrm{b} 2=0,492$ mengindikasikan bahwa, dengan meningkatnya tingkat kelahiran sebesar $1 \%$ maka dinamika populasi akan bertambah sebesar 0,492\%, Citerus peribus. b0 $=3,086$ memiliki arti bahwa apabila faktor $\mathrm{X}_{1}$ (jumlah induk) dan $\mathrm{X}_{2}$ (tingkat kelahiran) dianggap tetap (Citerus peribus) maka $\mathrm{Y}=$ 3,086 satuan.

Mengetahui pengaruh yang disumbangkan oleh kedua faktor $\left(\mathrm{X}_{1}\right.$ dan $\left.\mathrm{X}_{2}\right)$ secara bersama-sama terhadap perkembangan populasi usaha ternak babi (Y) maka dilakukan analisis ragam. Berdasarkan hasil analisis varians diketahui bahwa $\mathrm{F}_{\text {hitung }}=146,270$ $(\mathrm{P}<0,01)$ (Tabel 3). Hal ini mengartikan bahwa regresi perkembangan populasi $(\mathrm{Y})$ atas faktor-faktor mempengarui (X) bersifat nyata, dan ada pengaruh yang nyata dari faktor-faktor yang diidentifikasi yaitu jumlah induk $\left(\mathrm{X}_{1}\right)$ dan tingkat kelahiran $\left(\mathrm{X}_{2}\right)$ terhadap perkembangan populasi ternak babi program PERAK. Dengan kata lain bahwa persamaan regresi tersebut dapat digunakan untuk meramalkan perkembangan populasi ternak babi program PERAK apabila kedua faktor tersebut diketahui.

Berdasarkan hasil penelitian diperoleh koefisien determinasi berganda $\left(\mathrm{R}^{2}\right)$ dari persamaan regresi sebesar 0,75. Hal ini berarti variasi atau keragaman perkembangan populasi ternak babi program PERAK dapat dijelaskan secara bersama-sama oleh faktorfaktor yang diidentifikasi tersebut sebesar $75 \%$ sedangkan sisanya $25 \%$ dijelaskan faktor-faktor lain yang tidak diperhitungkan dalam penelitian ini.

\section{Pendapatan Usaha Ternak Babi}

Pendapatan seseorang dapat mencerminkan besarnya permintaan akan suatu produk/barang khususnya peternakan yakni ternak babi. Semakin tinggi pendapatan yang diperoleh maka semakin tinggi pula jumlah permintaan akan ternak babi.

Biaya usaha ternak babi Perak yang dianalisis dalam hal ini terdiri dari biaya tetap dan biaya variabel. Total biaya tetap sebesar Rp182.743 yang terdiri dari biaya penyusutan kandang. Total biaya variabel adalah sebasar Rp6.094.650 terdiri dari biaya pakan Rp6.036.400 yang diperoleh dari ratarata harga semua bahan yang di gunakan 
Tabel 4. Rata-rata komposisi biaya dan penerimaan usaha ternak babi program PERAK di Kabupaten Ngada

\begin{tabular}{lcc}
\hline Komponen & Total (Rp) & Persentase (\%) \\
\hline Biaya & & \\
Biaya tetap (1) & 182.753 & 11 \\
$\quad$-Kandang & 182.753 & \\
Total biaya tetap & & \\
Biaya Variabel (2) & 6.036 .400 & 2 \\
$\quad$-Pakan & 58.250 & 100 \\
$\quad$-Obat-obatan & 6.094 .650 & \\
\hline Total biaya variabel & 6.277 .403 & \\
\hline Total biaya (1+2) & & 19 \\
\hline Penerimaan & & 31 \\
Penjualan Ternak babi & 2.712 .000 & 49 \\
$\quad$-Anak/ekor/Ut & 4.459 .016 & 100 \\
$\quad$-Muda/ekor/Ut & 7.000 .000 & \\
$\quad$-Dewasa/ekor/Ut & 14.171 .016 & \\
\hline Total Penerimaan & 7.893 .613 & \\
\hline Pendapatan (B-A) & & \\
\hline
\end{tabular}

Sumber: Data primer 2019

sebagai pakan ternak yakni: batang pisang Rp1.055.600, talas Rp3.062.800, dedak Rp1.783.500, ampas kelapa Rp321,529, dan labu jepang Rp58,671 (Tabel 4). Ratarata persentase biaya pakan di daerah penelitian sebesar $86 \%$, hal ini sesuai dengan pendapat (Prasetya, 2012) yang menyatakan bahwa biaya pakan dapat mencapai $70-$ $80 \%$. Biaya perawatan kesehatan sebesar Rp64,000 diperoleh dari rata-rata biaya pemberian vitamin Rp10,000/ekor dan antibiotik Rp15,000/ekor. Hasil analisis data menunjukkan bahwa total biaya yang dikeluarkan sebesar Rp6.277.403.

Total penerimaan sebesar Rp14.171.016 terdiri dari penjualan ternak babi yakni babi anak, babi muda, dan babi dewasa. Penjualan babi anak diketahui rata-rata 1 unit ternak sebesar Rp8.784.946 sedangkan penjualan di tingkat unit ternak hanya 0,31 sehingga penerimaan dari penjualan babi anak sebesar Rp2.712.366. Rata-rata penjualan babi muda per 1 unit ternak sebesar Rp13.893.443 sedangkan penjualan di tingkat unit ternak hanya 0,33 UT sehingga penerimaan sebesar Rp4.459.016. Untuk babi dewasa 1 unit ternak sebesar Rp12.711.039 sedangkan penjualan di tingkat unit ternak hanya 0,56 sehingga penerimaan penjualan babi dewasa sebesar Rp7.000.000. Berdasarkan hasil analisis menggambarkan bahwa nilai rata-rata pendapatan tunai dari usaha ternak babi di daerah penelitian mencapai Rp7.893.613 per tahun usaha.

\section{Analisis SWOT}

Data dari hasil wawancara dengan stakeholder terkait, diidentifikasi faktorfaktor yang menjadi kekuatan dan kelemahan internal usaha ternak babi program PERAK serta peluang dan ancaman dari luar sebagaimana diuraikan berikut:

\section{Kekuatan (Strength)}

Faktor-faktor yang menjadi kekuatan yaitu:

1. Pemeliharaan ternak babi di Kabupaten Ngada merupakan suatu budaya.

2. Memelihara babi unggul lebih 
menguntungkan jika dibandingkan dengan babi lokal.

3. Lahan pakan dan pakan ternak babi tersedia.

4. Tersedia limbah hasil pertanian untuk pakan ternak babi.

5. Peternak babi dalam usia produktif.

\section{Kelemahan (Weakness)}

Faktor-faktor yang merupakan

kelemahan adalah sebagai berikut:

1. Kualitas SDM peternak rendah.

2. Teknologi beternak tradisional.

3. Keterbatasan modal usaha.

4. Rumah tangga peternak berasal dari KK miskin.

5. Angka kematian ternak babi tinggi.

\section{Peluang (opportunity)}

Faktor-faktor yang merupakan peluang adalah sebagai berikut:

1. Teknologi inseminasi buatan (IB) dan informasi teknologi pengolahan pakan ternak tersedia.

2. Permintaan pasar ternak babi hidup dan daging babi tinggi.

3. Tersedianya bantuan modal untuk pengadaan ternakbabitanpapengembalian (hibah).

4. Dukungan kebijakan pembangunan ternak babi dari pemerintah.

5. Kontribusi usaha ternak babi terhadap pendapatan.

\section{Ancaman (Threats)}

Faktor-faktor yang merupakan ancaman adalah sebagai berikut:

1. Tuntutan kualitas, kuantitas, dan kontinuitas produk peternakan.

2. Terbukanya jaringan perdagangan bebas.

3. Ada usaha sejenis di daerah lain.

4. Tersedia produk substitusi dengan harga lebih murah.

5. Bantuan modal usaha ternak babi dengan pola hibah.

Dari paparan analisa SWOT di atas, maka diperoleh strategi-strategi alternatif yang dapat diterapkan dalam pengembangan ternak babi program PERAK, di Kabupaten Ngada sebagai berikut:

1. Strategi Kekuatan-Peluang (S-O) Meningkatkan populasi ternak babi program PERAK

- Memperbaiki kualitas genetik ternak babi program PERAK dengan teknologi inseminasi buatan (IB).

- Memanfaatkan bantuan modal usaha dari pemerintah secara baik.

- Membangun kerja sama dengan pelaku pemasaran (pedagang lokal, antar kabupaten) sehingga dapat meningkatkan keuntungan.

- Mengoptimalkan pengolahan produk peternakan lainnya seperti feses dan urin untuk dijadikan pupuk.

2. Strategi Kelemahan-Peluang (W-O)

- Meningkatkan kemampuan SDM peternak dengan melakukan penyuluhan tentang pentingnya IB dan kawin alam, manajemen reproduksi serta penanganan pasca kelahiran sehingga mampu meningkatkan pendapatan usaha ternak babi.

- Memanfaatkan dukungan pemerintah untuk pengembangan usaha ternak babi dan bantuan modal usaha yang diberikan guna meningkatkan produksi dan produktivitas ternak.

3. Strategi Kekuatan-Ancaman (S-T)

- Pemanfaatan teknologi IB guna meningkatkan mutu ternak.

- Pemerintah membuat kebijakan pembatasan keluar masuk ternak babi dari daerah lain.

- Perlu bantuan lainnya berupa ternak unggas guna menopang kebutuhan hidup peternak dan keberlanjutan usaha ternak babi.

4. Strategi KelemahanAncaman (WT)

- Meningkatkan kualitas SDM peternak

- Memanfaatkan usaha usaha tambahan 
berupa ternak ternak unggas dan tanaman holtikultura untuk meningkatkan usaha ternak babi.

Berdasarkan matriks analisis SWOT maka diperoleh bebarapa alternatif strategi yang dapat diterapkan dalam pengembangan ternak babi program PERAK di Kabupaten Ngada sebagai berikut:

1. Strategi peningkatan populasi ternak babi program PERAK, melalui kegiatan:

- Perbaikan mutu genetik ternak melalui pemanfaatan bantuan ternak bibit dan teknologi IB.

2. Strategi peningkatan kualitas sumberdaya manusia (SDM) melalui kegiatan:

- Pelatihan dan pendampingan peternak babi program PERAK tentang sistim pemeliharaan ternak babi, kewirausahaan dan manajemen agribisnis.

3. Strategi optimalisasi penggunaan sumberdaya alam melalui kegiatan:

- Optimalisasi penggunaan lahan dan produksi limbah pertanian sebagai pakan ternak babi.

4. Strategi pengembangan dan penerapan teknologi melalui:

- Optimalisasi kegiatan penyuluhan kepada peternak tentang pentingnya IB.

\section{KESIMPULAN}

Berdasarkan hasil analisis dan pembahasan maka dapat ditarik kesimpulan bahwa:

1. Faktor-faktor yang mempengarui perkembangan populasi ternak babi program PERAK yakni jumlah induk $\left(\mathrm{X}_{1}\right)$ dan tingkat kelahiran $\left(\mathrm{X}_{2}\right)$. Hasil perhitungan koefisien determinasi $\left(\mathrm{R}^{2}\right)$ diperoleh variasi atau keragaman perkembangan populasi ternak babi program PERAK dapat dijelaskan secara bersama-sama oleh faktor-faktor yang di identifikasi sebesar $75 \%$, sedangkan sisanya $25 \%$ dijelaskan faktor-faktor lain yang tidak diperhitungkan.

2. Usaha ternak babi program PERAK di Kabupaten Ngada menyumbangkan pendapatan tunai sebesar Rp7.893.613 per tahun.

3. Analisis SWOT posisi usaha ternak babi program PERAK di Kabupaten Ngada berada pada kuadran 1 dan posisi ini merupakan situasi yang sangat menguntungkan. Strategi yang harus diterapkan dalam kondisi ini adalah mendukung kebijakan pertumbuhan yang agresif (growthoriented strategy).

Strategi yang perlu diterapkan atau direkomendasikan adalah:

1. Strategi peningkatan populasi ternak babi program PERAK.

2. Strategi peningkatan sumberdaya manusia (SDM).

3. Strategi optimalisasi penggunaan sumberdaya alam.

4. Strategi pengembangan dan penerapan teknologi

\section{DAFTAR PUSTAKA}

Ardana, I. B. K., Putra, D. K. dan Harya. 2008. Ternak Babi (Manajemen Reproduksi, Produksi, dan Penyakit). Udayana University Press. Bali.

Badan Pusat Statistik [BPS] Kabupaten Ngada. 2010. Kabupaten Ngada dalam angka 2010. Badan Pusat Statistik Nusa Tenggara Timur, Kupang. Badan Pusat Statistik Kabupaten Ngada. https:// ngadakab.bps.go.id/

Badan Pemberdayaan Masyarakat dan Pemerintahan Desa dan Pemberdayaan Perempuan (BPMPD-PP) Kabupaten Ngada. 2010.

Dinas Pertanian, Perkebunan, Peternakan [P3] Kabupaten Ngada. 2011. Petunjuk teknis pengembangan ternak perak. Dinas pertanian perkebunan peternakan Kabupaten Ngada. 
Abdurahman dan Muhidin. 2007. Analisis Korelasi, Regresi, dan Jalur dalam. Penelitian. Bandung: Pustaka Setia.

Prasetya, H. 2012. Semakin hoki dengan beternak babi. Pustaka baru press, Jogjakarta.

Prasetyo, H., Ardana, I. K. dan Budiasa, M. K. 2013. Studi Penampilan Reproduksi (Litter Size, Jumlah Sapih, Kematian) Induk Babi pada Peternakan Himalaya, Kupang. Indonesia Medicus Veterinus. 2(3): 261-268.

Purba, I. O., Budiasa, M. K. dan Ardana, I. K. 2014. Penampilan Reproduksi Induk Babi Landrace yang Dipelihara
Secara Intensif di Kabupaten Badung. Indonesia Medicus Veterinus. 3(2): 163-168.

Putri, S. S. 2018. Strategi Pengembangan Usaha Peternakan Babi Bali Untuk Meningkatkan Perekonomian Masyarakat Pedesaan Di Kecamatan Nusa Penida, Provinsi Bali. Simodos.

Rangkuti. 2015. Swot balance score card. Teknik menyusun strategi korporat yang efektif plus cara mengelola risiko. Cetakan ke 8. Gramedia Pustaka Utama, Jakarta.

Soekartawi. 2003. Teori ekonomi produksi. PT. Raja Grafindo Persada, Jakarta. 